\title{
PENGARUH OLEORESIN DAUN KAYU MANIS (Cinnamomum burmanii) DUA TAHAP TERHADAP KARAKTERISTIK EDIBLE FILM TAPIOKA
}

\author{
Rohula Utami*, Lia Umi Khasanah, Katut Kompi Yuniter dan Godras Jati Manuhara \\ Program Studi Ilmu dan Teknologi Pangan, Fakultas Pertanian, Universitas Sebelas Maret \\ *Corresponding author: rohulautami@staff.uns.ac.id
}

\begin{abstract}
Synthetic packaging caused negative impacts on environmental pollution. Utilization of edible film packaging is more effective than synthetic packaging due to the biodegradable properties. The two stages cinnamon leaves oleoresin contain active compounds that performed the antimicrobial and antioxidant activity. In this study, addition of two stages cinnamon leaves oleoresin on edible tapioca film can affect the characteristics of the edible film. Effect of two stages cinnamon leaves oleoresin on edible films characteristics was investigated. The results showed that the addition of two stages cinnamon leaves oleoresin $(0 \%, 0.025 \%, 0.5 \%, 0.075 \%$, and $0.1 \%)$ does not affect the thickness, tensile strength, and water vapor transmission rate of edible film, while affected the elongation and microbial inhibition of edible film. The edible film with the addition of $0.1 \%$ two stages cinnamon leaves oleoresin resulted the best microbial inhibition and physical characteristics of edible film with the thickness of $0.128 \mathrm{~mm}$, tensile strength of $0.2189 \mathrm{MPa}$, elongation of $283.2721 \%$, water vapor transmission rate of $29.786 \mathrm{~g} / \mathrm{jam} . \mathrm{m}^{2}$, and microbial inhibition zone of $31.394 \mathrm{~mm}$.
\end{abstract}

Keywords: Cinnamomum burmanii; Cinnamon leaves; Edible film; Oleoresin; Tapioca

Cite this as: Utami, R., Khasanah, L., Yuniter, K., \& Manuhara, G. 2017. Pengaruh Oleoresin Daun Kayu Manis (Cinnamomum burmanii) Dua Tahap terhadap Karakteristik Edible Film Tapioka. Caraka Tani: Journal of Sustainable Agriculture. 32(1), 55-67. doi: http://dx.doi.org/10.20961/carakatani.v32i1.15474

\section{PENDAHULUAN}

Pengemas dapat melindungi bahan pangan dari kerusakan. Bahan pengemas dari plastik banyak digunakan dengan pertimbangan ekonomis. Namun penggunaan material sintetis untuk membuat bahan pengemas plastik berdampak pada pencemaran lingkungan dan sulit terurai (Bao dan Hanh, 2008). Hal ini membuka peluang penerapan teknologi pengawetan pangan menggunakan pengemasan berbasis edible film.

Edible film merupakan pengemas berupa lapisan tipis yang digunakan untuk melapisi bahan pangan, berfungsi sebagai penahan transfer massa (air, oksigen, dan lemak) (Krochta dan Johnson, 1997). Bahan utama edible coating/film dikelompokkan menjadi tiga, yaitu hidrokoloid, lipida, dan komposit. Hidrokoloid yang tersedia melimpah di alam, mudah terurai (biodegradable), murah, dan mudah diperoleh adalah pati. Pati mempunyai sifat-sifat yang sesuai untuk bahan edible coating/film karena dapat membentuk film yang kuat (Bourtoom, 2008). Pati tapioka merupakan salah satu pati yang dapat digunakan untuk pembuatan edible film yang mempunyai kelebihan, yaitu tidak berasa dan berbau, transparan, dan non toksik (Lagos et al., 2015), serta kandungan amilosanya sebesar $17 \%$ berperan dalam pembentukan matrik polimer film yang rapat dan kuat (Tongdeesoontorn et al., 2011). Namun, edible film berbasis pati mempunyai kelemahan, yaitu resistensinya terhadap air rendah karena sifat hidrofilik pati dapat mempengaruhi stabilitas dan sifat mekanisnya (Sepheri dan Armin, 2015). Untuk meningkatkan karakteristik fisik maupun fungsional dari film pati, perlu dilakukan penambahan biopolimer atau bahan lain, antara lain bahan yang bersifat hidrofobik dan atau yang memiliki sifat antimikroba (Winarti, 2012).

Pengembangan pengemas aktif dengan penambahan antimikroba mampu memperbaiki mikrostruktur film, sifat mekanik (kekuatan tarik dan persen pemanjangan), sifat penghalang (permeabilitas uap air dan oksigen), dan penghambatan mikroorganisme (Souza et al., 2013). Beberapa jenis bahan antimikroba yang dapat ditambahkan ke dalam pengemas edible 
coating/film antara lain minyak atsiri yang berasal dari kayu manis (Tasia, 2014), lada (Yustina, 2012), cengkih (Towaha, 2012), bawang putih (Sari et al., 2014), daun sirih (Suliantari, 2008), sereh dapur (Resianingrum et al., 2016), rimpang temulawak (Anggraini et al., 2013), kunyit putih (Utami et al., 2013), lengkuas merah (Azzahra et al., 2013), dan oleoresin dari daun jeruk purut satu tahap (Kawiji et al., 2013b), kulit kayu manis (Sabrina et al., 2014), daun jeruk purut dua tahap (Utami et al., 2017), serta Ponce et al. (2008) yang membuat edible coating dengan penambahan oleoresin (zaitun, rosemary, paprika, dan bawang putih).

Kayu manis (Cinnamomum burmanii) merupakan tanaman yang kulit batang, cabang, serta dahannya dapat digunakan sebagai bahan rempah-rempah, dan merupakan salah satu komoditas ekspor Indonesia (Susanti, 2013). Kulit batang dan daun kayu manis yang diolah menjadi minyak atsiri maupun oleoresin dapat berperan sebagai antioksidan dan antimikroba (Singh et al., 2007). Daun kayu manis selama ini masih kurang dimanfaatkan. Penelitian Tampubolon (2011) menunjukkan kandungan sinamaldehida sebesar $63,61 \%$ pada minyak atsiri daun kayu manis. Senyawa aktif mayoritas pada minyak atsiri daun kayu manis pada penelitian Khasanah et al. (2014) adalah L-linalool (27,73\%). Sedangkan menurut Nugraheni (2012) senyawa aktif dalam minyak atsiri daun kayu manis adalah L-linalool $(34,40 \%), \quad 1,8$-cineole $(18,18 \%), \quad \alpha$-pinene $(13,96 \%), \beta$-pinene $(9,30 \%)$, dan benzyl benzoat $(4,42 \%)$.

Selain minyak atsiri, daun kayu manis dapat diolah menjadi oleoresin. Khasanah et al. (2017b) menyatakan bahwa oleoresin daun kayu manis satu tahap mempunyai kadar minyak atsiri 9,5\%, dengan senyawa aktif eugenol $59,56 \%$, oleic acid amide 19,58\%, dan benzyl benzoat 7,78\%. Sedangkan dari penelitian yang dilakukan Khasanah et al. (2017a) diketahui oleoresin daun kayu manis dua tahap mempunyai kadar minyak atsiri 22,22\%. Senyawa aktif terbesar yang dihasilkan berupa benzyl benzoate (39,67\%), linalool $(15,03 \%)$, cineole $(12,45 \%)$, $\alpha$-pinene (4,53\%), dan rhodium (3,1\%). Kandungan senyawa aktif mayoritas eugenol dalam minyak atsiri dan oleoresin daun kayu manis dapat berfungsi sebagai antimikroba dan antioksidan (Singh et al., 2007).

Senyawa aktif yang terdapat pada minyak atsiri dan oleoresin terus dikembangkan pemanfaatannya untuk pengawetan produk pangan. Tujuan penelitian ini adalah mengetahui karakteristik fisik (ketebalan, kuat tarik, pemanjangan, permeabilitas uap air) dan penghambatan mikroba edible film dengan penambahan oleoresin daun kayu manis dua tahap dengan variasi konsentrasi $0 \%, 0,025 \%, 0,05 \%$, $0,075 \%$, dan $0,1 \%$.

\section{METODE PENELITIAN}

\section{Bahan}

Daun kayu manis (Cinnamomum burmanii) diperoleh dari Desa Bubakan, Girimanto Wonogiri. Proses ekstraksi ampas daun kayu manis menggunakan pelarut etanol $70 \%$ yang diperoleh dari toko bahan kimia Agung Jaya, Yosodipuro, Solo. Bahan edible film menggunakan pati tapioka "Rose Brand", plasticizer berupa gliserol "PT. Soci Mas (Sinar Mas), aquades dan oleoresin. Bakteri Pseudomonas fluorescens FNCC 0071 diperoleh dari PSPG UGM.

\section{Destilasi Daun Kayu Manis}

Daun kayu manis yang diperoleh disortasi untuk memisahkan daun yang bagus dan rusak. Daun kayu manis yang bagus yang akan dipakai untuk proses destilasi atau penyulingan. Sebelum penyulingan dilakukan pretreatment terhadap daun kayu manis yaitu pengeringan dan perajangan. Pengeringan dilakukan dengan kering angin selama 5 hari, diperoleh kadar air daun kayu manis setelah pengeringan sebesar $10 \%$. Setelah itu dirajang secara acak untuk mengecilkan ukuran daun kayu manis (Khasanah et al., 2017a). Penyulingan minyak atsiri daun kayu manis dilakukan dengan destilasi uap air. Proses destilasi berlangsung selama 3 jam. Penyulingan ini akan menghasilkan minyak atsiri daun kayu manis.

\section{Ekstraksi Ampas Sisa Destilasi Minyak Atsiri}

Ampas sisa destilasi minyak atsiri diekstraksi dengan menggunakan pelarut langsung pada bahan. Pelarut yang digunakan adalah etanol $70 \%$. Perbandingan bahan dan pelarut yang akan diekstraksi yaitu 1:6. Ekstraksi dilakukan pada suhu $78^{\circ} \mathrm{C}$ selama 5 jam 9 menit (Khasanah et al., 2017a). Proses ekstraksi maserasi ini menghasilkan filtrat oleoresin yang masih mengandung pelarut. Filtrat oleoresin yang didapatkan diuapkan dengan rotary evaporator 
untuk menghilangkan pelarut yang masih terkandung dalam oleoresin dengan suhu $80{ }^{\circ} \mathrm{C}$ dengan kecepatan $120 \mathrm{rpm}$ selama 1,5 jam. Evaporasi dihentikan ketika oleoresin sudah kental dan pelarut sudah tidak menetes. Setelah tidak ada pelarut menetes proses evaporasi dilanjutkan selama 30 menit (Khasanah et al., 2017a).

\section{Blending Minyak Atsiri dan Oleoresin Ampas Daun Kayu Manis Sisa Destilasi}

Blending adalah proses pencampuran minyak atsiri dan oleoresin ampas daun kayu manis sisa destilasi sehingga dihasilkan oleoresin dua tahap. Banyaknya rendemen minyak atsiri dan oleoresin ampas daun kayu manis dihitung berdasarkan perolehan dan berat bahan yang digunakan dari masing-masing proses. Pencampuran minyak atsiri dan oleoresin menggunakan perbandingan yang sama dari berat bahan awal yang digunakan pada setiap proses (Khairina, 2014). Oleoresin dan minyak atsiri diaduk perlahan dengan spatula, agar percampuran merata.

\section{Pembuatan Edible Film}

Pembuatan edible film menggunakan $5 \mathrm{~g}$ pati tapioka, aquades $100 \mathrm{ml}$, gliserol $2 \mathrm{ml}$, oleoresin dua tahap dengan variasi konsentrasi yang berbeda yaitu $0 \%, 0,25 \%, 0,5 \%, 0,75 \%$, dan $1 \%$ dari banyaknya aquades yang digunakan. Proses pembuatannya diawali dengan pengadukan 5 gram pati tapioka dalam $100 \mathrm{ml}$ aquades kemudian dipanaskan $70{ }^{\circ} \mathrm{C}$ sampai larutan tergelatinisasi. Selanjutnya ditambahkan gliserol sebanyak $2 \mathrm{ml}$, pencampuran dilakukan dengan pemanasan $60{ }^{\circ} \mathrm{C}$ selama 30 menit (Utami et al., 2014). Kemudian didinginkan hingga $30{ }^{\circ} \mathrm{C}$ dan dilakukan penambahan oleoresin daun kayu manis dua tahap $(0 \%, 0,25 \%, 0,5 \%, 0,75 \%$, dan $1 \%$ ) dengan pengadukan menggunakan magnetic stirrer. Setelah bercampur dengan rata, larutan sudah terlihat homogen kemudian dituangkan pada nampan pencetak $(22 \times 15 \mathrm{~cm})$. Selanjutnya proses pengeringan menggunakan cabinet dryer pada suhu $75{ }^{\circ} \mathrm{C}$ selama 5 jam (Ayuningrum, 2015). Pembuatan sampel dilakukan masingmasing dua ulangan yang telah jadi akan dianalisis karakteristik fisik. Analisis edible film yang dilakukan meliputi uji ketebalan (Mc Hugh et al., 1994), uji kuat tarik, uji pemanjangan, uji laju transmisi uap air (Gontard et al., 1993), dan uji penghambatan mikroba (Manab et al., 2011).

\section{Analisis Statistik}

Data hasil penelitian dianalisis menggunakan ANOVA untuk mengetahui pengaruh perbedaan perlakukan pada tingkat signifikansi $5 \%$. Selanjutnya dengan pengujian Duncan Multiple Range Test (DMRT) pada tingkat signifikansi 5\%.

\section{HASIL DAN PEMBAHASAN}

Pada penelitian ini didapatkan rendemen minyak atsiri sebesar $0,125 \%$. Rendemen minyak atsiri pada penelitian ini lebih besar dari penelitian Khasanah et al. (2014) 0,116\%, Nugraheni (2012) 0,1016\% dan Khasanah et al. (2017a) 0,095\%. Pada proses maserasi rendemen oleoresin ampas destilasi daun kayu manis yang didapatkan sebesar 8,611\%. Rendemen oleoresin pada penelitian ini lebih sedikit dari penelitian Khasanah et al. (2017a) 10,7 \% dan Khairina (2014) $11,9 \%$. Perbedaan rendemen minyak atsiri dan oleoresin pada penelitian ini disebabkan oleh proses pengeringan yang optimal (Khairina, 2014). Pengeringan yang optimal akan memudahkan proses destilasi dan ekstraksi untuk menghasilkan minyak atsiri dan oleoresin yang lebih besar. Semua oleoresin dari ampas destilasi yang didapatkan pada penelitian ini digunakan untuk membuat oleoresin daun kayu manis dua tahap, sehingga dilakukan blending 73,195 g oleoresin ampas destilasi dengan minyak atsiri daun kayu sebesar 1,06 ml.

\section{Ketebalan}

Ketebalan edible film merupakan parameter yang penting karena akan mempengaruhi tujuan penggunaannya sebagai pengemas produk. Ketebalan berpengaruh terhadap laju transmisi uap air dan gas. Semakin tinggi nilai ketebalan film maka sifatnya akan semakin kaku dan keras serta produk yang dikemas akan semakin aman dari pengaruh luar. Edible film yang dihasilkan diukur ketebalannya pada 5 titik yang berbeda kemudian dirata-rata (Mc Hugh et al., 1994).

Berdasarkan Tabel 1 ketebalan edible film dengan penambahan oleoresin daun kayu manis dua tahap dengan konsentrasi $0 \%, 0,025 \%$, $0,05 \%, 0,075 \%$ dan $0,1 \%$, yaitu: $0,1370 \mathrm{~mm}$, $0,115 \mathrm{~mm}, 0,1480 \mathrm{~mm}, 0,1495 \mathrm{~mm}$, dan 0,1280 $\mathrm{mm}$. Pada tingkat signifikansi $5 \%$ dengan pengujian ANOVA, variasi konsentrasi oleoresin daun kayu manis tidak berpengaruh secara signifikan terhadap ketebalan edible film yang diperoleh $(\rho>0,05)$. Pada penelitian ini film 
dengan penambahan oleoresin daun kayu manis dua tahap, semakin banyak konsentrasi yang ditambahkan akan menambah banyaknya total padatan dalam larutan sehingga menghasilkan film yang semakin tebal sampai pada konsentrasi $0,075 \%$. Namun mengalami penurunan ketebalan pada konsentrasi $0,1 \%$. Hal ini karena pada konsentrasi oleoresin daun kayu manis yang lebih tinggi mempunyai kandungan minyak atsiri yang semakin besar sehingga akan terjadi interaksi minyak dengan permukaan film membentuk kekompakan matrik yang semakin kuat (Pires et al., 2011).

Tabel 1. Pengaruh Konsentrasi Oleoresin Daun Kayu Manis Dua Tahap terhadap Ketebalan Edible film

\begin{tabular}{cc}
\hline Konsentrasi Oleoresin & Ketebalan Edible film $(\mathrm{mm})$ \\
\hline $0 \%$ & $0,1370 \mathrm{a} \pm 0,001$ \\
$0,025 \%$ & $0,1115 \mathrm{a} \pm 0,004$ \\
$0,050 \%$ & $0,1480 \mathrm{a} \pm 0,016$ \\
$0,075 \%$ & $0,1495 \mathrm{a} \pm 0,028$ \\
$0,10 \%$ & $0,1280 \mathrm{a} \pm 0,006$ \\
\hline
\end{tabular}

Keterangan: Angka yang diikuti huruf superscript yang sama menunjukkan tidak beda nyata pada taraf signifikansi 5\% $(\alpha=0,05)$ dengan menggunakan uji ANOVA.

Ketebalan edible film pada penelitian ini hampir sama edible film tapioka minyak atsiri kulit batang kayu manis yang berkisar antara 0,114-0,176 mm (Ayuningrum, 2015), dan edible film tapioka CMC 0,120-0,160 mm (Tongdeesoontorn et al., 2011). Namun lebih tipis dari edible film tapioka minyak atsiri sereh dapur yang mempunyai ketebalan 0,143-0,189 mm (Resianingrum et al., 2016). Jika dibandingkan dengan bahan pembuatan film yang berbeda edible film pada penelitian ini lebih tebal dari nilai rata-rata ketebalan edible film pati kimpul dan kalium sorbat, yaitu 0,065-0,081 mm (Warkoyo, 2014), dan edible film pektin kulit pisang kepok mempunyai ketebalan 0,0444-0,0678 mm (Rofikah, 2013). Namun edible film penelitian ini lebih tipis dari edible film komposit maizena dan glukomanan yang mempunyai ketebalan 0,1613 0,1828 mm (Siswanti et al., 2013), dan edible film albumin 0,141-0,168 mm (Taqi et al., 2011).

Standar ketebalan edible film kurang dari 0,25 mm (Skurtys et al., 2011). Ketebalan film yang kecil akan memudahkan film terkena pengaruh luar, sehingga produk yang dikemas akan rentan mengalami kerusakan. Sedangkan ketebalan film yang semakin besar akan membuat film dapat mempertahankan produk lebih lama karena dapat menurunkan laju uap air, gas, dan senyawa volatil lainnya (Yulianti, 2012). Namun ketebalan film yang terlalu tebal akan mempengaruhi kenampakan, rasa, dan tekstur produk yang dikemas (Taqi et al., 2011). Rahayoe et al. (2014) juga menjelaskan bahwa ketebalan edible film yang terlalu tipis, akan sedikit atau bahkan tidak ada pengaruhnya terhadap produk yang dikemas. Mc Hugh et al. (1994) juga menyatakan bahwa semakin tebal edible film akan memberikan warna yang tidak transparan dan penampakan produk menjadi kurang menarik.

Ketebalan film dapat dikontrol dengan mengukur volume larutan pembentuk edible film (Zhong dan Xia, 2008). Park et al. (1996) menyatakan bahwa ketebalan edible film dipengaruhi oleh luas cetakan, volume larutan, dan banyaknya total padatan dalam larutan.

\section{Kuat Tarik}

Maghfiroh et al. (2013) menjelaskan bahwa kuat tarik merupakan gaya tarik maksimum yang dapat ditahan oleh film. Kuat tarik film menunjukkan kemampuan film untuk menahan beban sebelum mengalami kerusakan. Edible film dengan kekuatan tarik yang tinggi merupakan pengemas yang baik karena film menjadi tidak mudah sobek dan produk yang dikemas tidak mudah rusak.

Pada Tabel 2 kuat tarik edible film dengan penambahan oleoresin daun kayu manis dua tahap dengan konsentrasi $0 \%, 0,025 \%, 0,05 \%, 0,075 \%$, dan $0,1 \%$ berturut-turut sebesar $0,1088 \mathrm{MPa}$, 0,1349 $\mathrm{MPa}, 0,1636 \mathrm{MPa}, 0,0924 \mathrm{MPa}$, dan 0,2189 MPa. Hasil analisis ANOVA signifikansi 5\% menunjukkan bahwa perbedaan konsentrasi oleoresin daun kayu manis dua tahap yang ditambahkan tidak mempengaruhi secara signifikan $(\rho>0,05)$ terhadap kuat tarik edible film. Kuat tarik edible film yang ditambahkan oleoresin daun kayu manis dua tahap cenderung 
lebih besar daripada kuat tarik edible film tanpa penambahan oleoresin daun kayu manis dua tahap. Hal ini sama dengan kuat tarik edible film gelatin variasi minyak zaitun, penambahan minyak atsiri cenderung menghasilkan kuat tarik film yang lebih besar dari kontrol (Ma et al., 2012).

Tabel 2. Pengaruh Konsentrasi Oleoresin Daun Kayu Manis Dua Tahap terhadap Kuat Tarik Edible Film

\begin{tabular}{cc}
\hline Konsentrasi & Kuat Tarik Edible film (MPa) \\
\hline $0 \%$ & $0,1088^{\mathrm{a}} \pm 0,013$ \\
$0,025 \%$ & $0,1349^{\mathrm{a}} \pm 0,062$ \\
$0,050 \%$ & $0,1636^{\mathrm{a}} \pm 0,026$ \\
$0,075 \%$ & $0,0924^{\mathrm{a}} \pm 0,008$ \\
$0,10 \%$ & $0,2189^{\mathrm{a}} \pm 0,026$ \\
\hline
\end{tabular}

Keterangan: Angka yang diikuti huruf superscript yang sama menunjukkan tidak beda nyata pada taraf signifikansi 5\% $(\alpha=0,05)$ dengan menggunakan uji ANOVA.

Kuat tarik yang dimiliki edible film pada penelitian ini lebih kecil dari edible film tapioka minyak atsiri sereh dapur yang berkisar 0,16-0,52 MPa (Resianingrum, 2016), kuat tarik edible film tapioka minyak atsiri kulit batang kayu manis pada penelitian Ayuningrum (2015) 0,69-0,165 MPa dan Souza et al. (2013) 1,05-2,32 MPa, dan kuat tarik edible film albumin minyak zaitun 5,35 MPa (Taqi et al., 2011). Kuat tarik edible film penelitian ini hampir sama dengan kuat tarik edible film tepung jali pada kisaran 0,104-0,4 MPa (Bukhori et al., 2011) dan kuat tarik edible film ekstrak kedelai dengan penambahan tapioka dan gliserol sebesar 0,048-0,134 MPa (Sinaga et al., 2013).

Berdasarkan hasil tersebut dapat diketahui bahwa penambahan konsentrasi oleoresin daun kayu manis dua tahap yang semakin besar juga menghasilkan kuat tarik edible film yang semakin besar sampai pada konsentrasi $0,05 \%$. Peningkatan kuat tarik edible film ini terjadi karena semakin besar konsentrasi padatan yang ditambahkan mengakibatkan interaksi antar polimer yang semakin kuat sehingga menghasilkan kekuatan regang putus film juga semakin meningkat (Rofikah, 2013). Penurunan kuat tarik edible film dikarenakan gliserol menyebabkan ikatan hidrogen semakin renggang sehingga kuat tarik menurun. Adanya plasticizer akan meningkatkan elastisitas edible film, sehingga akan menurunkan kekuatan film (Mali et al., 2005).

Penambahan oleoresin daun kayu manis dua tahap sampai pada konsentrasi $0,05 \%$, menghasilkan kuat tarik edible film yang semakin meningkat, namun persen pemanjangannya mengalami penurunan. Nilai kuat tarik edible film yang semakin besar akan menurunkan fleksibilitas film, begitu juga sebaliknya (Nonsee et al., 2011). Terjadinya peningkatan dan penurunan kuat tarik juga dilaporkan Pires et al. (2011), yaitu edible film protein dengan penambahan minyak atsiri thimi. Dengan variari konsentrasi minyak thimi $0 \%, 0,025 \%, 0,05 \%$, $0,1 \%$, dan $0,25 \%$ menghasilkan kuat tarik berturut-turut 6,16 $\mathrm{MPa}, 6,67 \mathrm{MPa}, 4,13 \mathrm{MPa}$, 5,61 MPa, dan 4,33 MPa. Penambahan lipid terhadap bahan dasar pembentuk edible film akan mempengaruhi sifat mekanik film.

Detduangchan et al. (2014) menjelaskan kenaikan kuat tarik edible film disebabkan oleh kerapatan ikatan silang gugus hidroksil film yang meningkat. Sifat mekanik film tergantung pada formulasi bahan yang digunakan. Kuat tarik yang meningkat berarti fleksibilitas film menurun. Kuat tarik merupakan ukuran dasar dari kekakuan sebuah film. Peningkatan konsentrasi bahan menyebabkan peningkatan matrik film yang terbentuk sehingga film menjadi kuat (Nugroho et al., 2013).

\section{Persen Pemanjangan}

Persen pemanjangan edible film merupakan keadaan ketika film patah setelah mengalami perubahan panjang dari ukuran yang sebenarnya pada saat terjadi peregangan. Parameter ini dapat menunjukkan kemampuan edible film dalam menahan sejumlah beban sebelum edible film putus (Rofikah, 2013). Detduangchan et al. (2014) juga menjelaskan bahwa persen pemanjangan merupakan indikator fleksibilitas dan kemampuan peregangan edible film. Gontard et al. (1993) 
menyatakan bahwa pengukuran kuat tarik dan pemanjangan edible film dilakukan dengan mencetak edible film membentuk tapal kuda kemudian pengujiannya menggunakan alat Universal Testing Machine.

Berdasarkan Tabel 3 persen pemanjangan edible film dengan penambahan oleoresin daun kayu manis dengan konsentrasi $0 \%, 0,025 \%$, $0,5 \%, 0,075 \%$, dan $0,1 \%$ adalah $184,3218 \%$, $176,9072 \%, \quad 168,4672 \%, \quad 336,6399 \%$, dan 283,2721\%. Analisis ANOVA signifikansi 5\% menunjukkan bahwa variasi penambahan konsentrasi oleoresin daun kayu manis dua tahap berpengaruh signifikan $(\rho<0,05)$ terhadap hasil pemanjangan edible film. Hasil uji DMRT ( $\alpha=$ $0,05)$ persen pemanjangan edible film penambahan konsentrasi oleoresin daun kayu manis dua tahap $0 \%$ tidak berbeda nyata dengan persen pemanjangan pemanjangan edible film penambahan $0,025 \%$ dan $0,05 \%$, tetapi berbeda nyata dengan persen pemanjangan edible film konsentrasi oleoresin daun kayu manis dua tahap $0,075 \%$ dan 0,1\%. Film dengan konsentrasi oleoresin daun kayu manis dua tahap $0,075 \%$ mempunyai persen pemanjangan yang paling tinggi. Hal ini dikarenakan kuat tarik edible film konsentrasi $0,075 \%$ juga paling rendah.

Tabel 3. Pengaruh Konsentrasi Oleoresin Daun Kayu Manis Dua Tahap terhadap Pemanjangan Edible film

\begin{tabular}{cc}
\hline Konsentrasi & Pemanjangan Edible film (\%) \\
\hline $0 \%$ & $184,3218^{\mathrm{a}} \pm 15,494$ \\
$0,025 \%$ & $176,9072^{\mathrm{a}} \pm 2,395$ \\
$0,050 \%$ & $168,4672^{\mathrm{a}} \pm 41,881$ \\
$0,075 \%$ & $336,6399^{\mathrm{c}} \pm 5,362$ \\
$0,10 \%$ & $283,2721^{\mathrm{b}} \pm 8,995$ \\
\hline
\end{tabular}

Keterangan: Angka yang diikuti huruf superscript yang sama menunjukkan tidak beda nyata pada taraf signifikansi 5\% $(\alpha=0,05)$ dengan menggunakan uji ANOVA.

Penambahan oleoresin daun kayu manis dua tahap sampai konsentrasi $0,05 \%$ semakin menurunkan pemanjangan edible film namun kemudian mengalami peningkatan persen pemanjangan pada konsentrasi oleoresin yang $0,075 \%$. Penurunan elongation film ini disebabkan kekuatan tarik film yang meningkat yang menunjukkan film kuat, namun fleksibilitasnya menurun. Semakin besar nilai pemanjangan semakin baik edible film yang dihasilkan karena lebih elastis dan tidak mudah sobek. Jika nilainya lebih dari $50 \%$ elongation dikatakan baik dan dikatakan buruk jika nilainya kurang dari 10\% (Krochta dan Johnson, 1997). Sehingga dapat diketahui edible film tapioka oleoresin daun kayu manis dua tahap mempunyai persen pemanjangan yang bagus.

Terjadinya penurunan pemanjangan edible film pemanjangan juga dilaporkan Pires et al. (2011), yaitu edible film protein dengan penambahan minyak atsiri thimi. Dengan variari konsentrasi minyak thimi $0 \%, 0,025 \%, 0,05 \%$, $0,1 \%$, dan $0,25 \%$ menghasilkan persen pemanjangan berturut-turut $147,9 \%, 129,8 \%$, $119,1 \%, 146,3 \%$, dan $111,2 \%$. Penambahan lipid terhadap bahan dasar pembentuk edible film akan mempengaruhi sifat mekanik film.

Persen pemanjangan edible film ini hampir sama dengan pemanjangan edible film tapioka minyak atsiri kulit kayu manis berkisar 191,27256,13\% (Souza et al., 2013). Pemanjangan edible film pada penelitian ini lebih besar dari pemanjangan edible film tapioka minyak atsiri Zataria multiflora Boiss 94,38\%-162,45\% (Ghasemlou et al., 2010), edible film gelatin minyak atsiri Zataria multiflora 125-172\% (Kavoosi et al., 2014) dan edible film albumin minyak zaitun 79,12\% (Taqi et al., 2011).

Menurut Kusumawati et al. (2013) adanya kenaikan elongasi diduga dipengaruhi oleh adanya gliserol yang berperan sebagai plastisizer sehingga edible film menjadi lebih elastis. Gliserol memiliki berat molekul yang kecil sehingga dapat masuk ke dalam ikatan antarmolekul. Molekul gliserol akan mengganggu kekompakan pati, menurunkan interaksi intermolekuler dan meningkatkan mobilitas polimer sehingga mengakibatkan peningkatan elongasi. Interaksi gliserol dengan matriks pati akan mempengaruhi elastisitasnya. Sehingga dibutuhkan perbandingan yang sesuai antara 
gliserol, pati, dan oleoresin daun kayu manis dua tahap.

Pada umumnya, film yang terbuat dari pati mudah sekali rusak. Peningkatan konsentrasi bahan, akan menyebabkan peningkatan matrik yang terbentuk, sehingga film akan menjadi kuat. Namun, peningkatan konsentrasi bahan juga menyebabkan penurunan rasio gliserol sebagai plasticizer terhadap pati, sehingga mengakibatkan penurunan elongation film apabila terkena gaya, yang kemudian menyebabkan film mudah patah (Nugroho et al., 2013).

\section{Laju Transmisi Uap Air}

Nugroho et al. (2013) menjelaskan bahwa migrasi uap air biasanya terjadi pada bagian film yang hidrofilik. Sehingga nilai laju transmisi uap air film dipengaruhi oleh ratio antara bagian komponen film yang hidrofilik dan hidrofobik. Katili et al. (2013), juga menjelaskan bahwa permeabilitas uap air merupakan ukuran suatu bahan yang dapat dilalui oleh uap air. Transmisi uap air sangat dipengaruhi oleh suhu, RH (Relative Humidity), ketebalan film, jenis dan kosentrasi platicizer, serta sifat bahan dasar pembentuk edible film. Permeabilitas uap air edible film yang bersifat hidrofilik akan meningkat dengan ketebalan dari edible film yang semakin rendah.

Gontard et al. (1993) pengujian laju transmisi uap air edible film dilakukan dengan menentukan slope kenaikan berat cawan wvtr dan waktu inkubasi. Slope berbanding lurus dengan besarnya laju transmisi edible film. Semakin besar slope akan menghasilkan laju transmisi uap air yang semakin besar, begitu juga sebaliknya. Slope yang dihasilkan menunjukkan jumlah difusi uap air yang melewati film per satuan waktu (g/jam) (Detduangchan et al., 2014).

Pada Tabel 4, diketahui bahwa data edible film dengan penambahan oleoresin daun kayu manis dua tahap dengan konsentrasi $0 \%, 0,025 \%$, $0,05 \%, 0,075 \%$, dan $0,1 \%$ mempunyai laju transmisi uap air berturut-turut sebesar 27,321 $\mathrm{g} / \mathrm{jam} . \mathrm{m}^{2}, \quad 27,143 \mathrm{~g} / \mathrm{jam} . \mathrm{m}^{2}, \quad 28,143 \mathrm{~g} / \mathrm{jam} . \mathrm{m}^{2}$, $31,179 \mathrm{~g} / \mathrm{jam} . \mathrm{m}^{2}$, dan 29,786 g/jam.m ${ }^{2}$. Dengan analisis ANOVA $(\alpha=0,05)$ dapat diketahui bahwa variasi konsentrasi oleoresin daun kayu manis dua tahap tidak signifikan $(\rho>0,05)$ mempengaruhi laju transmisi uap air edible film. Laju transmisi uap air dipengaruhi oleh ketebalan film. Penambahan oleoresin daun kayu manis dua tahap pada penelitian ini juga tidak signifikan mempengaruhi ketebalan edible film. Ketebalan edible film mempengaruhi permeabilitas uap air edible film, ketebalan edible film yang semakin besar akan menurunkan laju transmisi uap air, sedangkan ketebalan edible film yang rendah akan menghasilkan laju transmisi uap air semakin besar (Belibi et al., 2014).

Tabel 4. Pengaruh Konsentrasi Oleoresin Daun Kayu Manis Dua Tahap terhadap Laju Transmisi Uap Air Edible film

\begin{tabular}{cc}
\hline Konsentrasi & Laju Transmisi Uap Air Edible film $\left(\mathrm{g} / \mathrm{jam} . \mathrm{m}^{2}\right)$ \\
\hline $0 \%$ & $27,321^{\mathrm{a}} \pm 1,16$ \\
$0,025 \%$ & $27,143^{\mathrm{a}} \pm 5,25$ \\
$0,050 \%$ & $28,143^{\mathrm{a}} \pm 0,51$ \\
$0,075 \%$ & $31,179^{\mathrm{a}} \pm 0,86$ \\
$0,10 \%$ & $29,786^{\mathrm{a}} \pm 0,20$ \\
\hline
\end{tabular}

Keterangan: Angka yang diikuti huruf superscript yang sama menunjukkan tidak beda nyata pada taraf signifikansi 5\% $(\alpha=0,05)$ dengan menggunakan uji ANOVA.

Laju transmisi uap air edible film pada penelitian ini lebih besar dari laju transmisi edible film tapioka minyak atsiri kulit batang kayu manis 21,38 g/jam.m ${ }^{2}$ (Ayuningrum, 2015) dan laju transmisi uap air edible film glukomanan 19,4321,64 g/jam.m ${ }^{2}$ (Siswanti et al., 2013). Edible film pada penelitian ini merupakan edible film berbasis pati, yaitu pati tapioka. Zhou et al. (2008) menjelaskan bahwa pati merupakan biopolimer yang sensitif terhadap kelembapan, sehingga dapat mempengaruhi sifat mekanik termoplastik pati, hal ini menunjukkan bahwa mengurangi sensitivitas kelembapan dan meningkatkan ketahanan air dapat memperbaiki permeabilitas uap air edible film berbasis pati. Nilai laju transmisi uap air dapat digunakan untuk mengetahui adanya mekanisme perpindahan 
massa dan interaksi polimer pada biodegradable film (Detduangchan et al., 2014).

Laju transmisi uap air yang tinggi dikarenakan permukaan film dengan penambahan oleoresin daun kayu manis mempunyai tekstur yang lebih elastis, sehingga resisten terhadap uap air. Bahan baku edible film dari pati yang termasuk kelompok hidrokoloid bersifat higroskopis. Film hidrokoloid biasanya mempunyai struktur mekanis yang cukup bagus namun kurang menghambat terhadap laju transmisi uap air (Krochta dan Johnson, 1997). Laju transmisi uap air yang semakin rendah menunjukkan edible film mempunyai kekuatan untuk menahan uap air yang lebih tinggi (Zhong dan Xia, 2008).

Laju transmisi uap air juga dipengaruhi oleh plasticizer yang digunakan. Pada penelitian ini menggunakan gliserol sebagai plasticizer. Menurut Gontard et al. (1993), gliserol dapat meningkatkan permeabilitas film terhadap uap air karena sifatnya yang hidrofilik. Gliserol merupakan senyawa alkohol polihidrat, biasanya disebut alkohol trivalent. Nonsee et al. (2011) menjelaskan bahwa upaya untuk mengurangi permeabilitas uap air edible film dapat dilakukan dengan inkorposari bahan lipid dalam film polisakarida yang hidrofilik.

\section{Penghambatan Mikroba}

Pada Tabel 5 dapat diketahui bahwa hasil analisis menggunakan ANOVA signifikansi 5\% menunjukkan bahwa variasi konsentrasi oleoresin daun kayu manis dua tahap berpengaruh secara signifikan $(\rho<0,05)$ terhadap peningkatan zona penghambatan edible film. Dengan menggunakan uji DMRT $(\alpha=0,05)$ penghambatan mikroba edible film penambahan konsentrasi konsentrasi $0 \%$ oleoresin daun kayu manis dua tahap berbeda nyata dengan penghambatan mikroba edible film penambahan konsentrasi $0,05 \%, 0,075 \%$, dan $0,1 \%$. Penghambatan mikroba ini dilakukan dengan mengukur zona bening yang terbentuk. Diameter zona bening yang diperoleh dari pengujian penghambatan mikroba edible film pada konsentrasi $0 \%, 0,025 \%, 0,05 \%, 0,075 \%$, dan $0,1 \%$ berturut-turut sebesar $21,766 \mathrm{~mm}$, 23,653 mm, 26,159 mm, 26,966 mm, dan 31,394 $\mathrm{mm}$. Berdasarkan hasil tersebut semakin banyak oleoresin daun kayu manis dua tahap pada edible film menghasilkan diameter zona bening yang semakin besar.

Tabel 5. Pengaruh Konsentrasi Oleoresin Daun Kayu Manis Dua Tahap terhadap Penghambatan Mikroba Edible film

\begin{tabular}{cc}
\hline Konsentrasi & Diameter Zona Bening Edible film $(\mathrm{mm})$ \\
\hline $0 \%$ & $21,766^{\mathrm{a}} \pm 0,69$ \\
$0,025 \%$ & $23,653^{\mathrm{ab}} \pm 1,50$ \\
$0,050 \%$ & $26,159^{\mathrm{b}} \pm 2,49$ \\
$0,075 \%$ & $26,966^{\mathrm{b}} \pm 1,43$ \\
$0,10 \%$ & $31,394^{\mathrm{c}} \pm 0,92$ \\
\hline
\end{tabular}

Keterangan: Angka yang diikuti huruf superscript yang sama menunjukkan tidak beda nyata pada taraf signifikansi 5\% $(\alpha=0,05)$ dengan menggunakan uji ANOVA.

Zona bening penghambatan mikroba Pseudomonas fluorescens pada edible film oleoresin daun kayu manis dua tahap ini lebih besar dari edible film tapioka minyak atsiri kulit batang kayu manis sebesar 13,75-28,6 mm (Ayuningrum, 2015), dan edible film tapioka minyak atsiri sereh dapur 25,89-26,05 $\mathrm{mm}$ (Resianingrum et al., 2016). Hampir sama dengan zona penghambatan edible film tapioka minyak atsiri temulawak, yaitu 27,56-33,22 mm (Kawiji et al., 2013a), dan edible film tapioka minyak atsiri kunyit putih 28,55-32,99 $\mathrm{mm}$ (Utami et al., 2013). Aktivitas antimikroba yang semakin besar akan semakin melindungi produk dari aktivitas mikroorganisme, sehingga produk menjadi lebih aman dan tahan lama (Emiroglu et al., 2010).

Semakin besar diameter zona bening yang terbentuk menunjukkan aktivitas antimikroba yang semakin besar pula. Oleoresin yang digunakan pada penelitian ini merupakan hasil olahan daun kayu manis berbentuk pasta kental yang dihasilkan dengan destilasi dan maserasi. Pada penelitian Khasanah et al. (2017a) oleoresin daun kayu manis dua tahap mempunyai kandungan senyawa aktif benzyl benzoate, linalool, cineole, $\alpha$-pinene, dan rhodium. 
Oleoresin merupakan campuran minyak atsiri dan resin, minyak atsiri daun kayu manis juga mengandung senyawa aktif yang berperan sebagai antimikroba (Singh et al., 2007). Senyawa aktif mayoritas pada minyak atsiri daun kayu manis berdasarkan Khasanah et al. (2014) dan Nugraheni (2012) adalah L-linalool. Senyawa aktif dalam minyak atsiri dapat berperan sebagai antimikroba sehingga dapat menghambat pertumbuhan mikroba (Singh et al., 2007).

Konsentrasi oleoresin daun kayu manis yang semakin besar akan menghasilkan edible film yang banyak mengandung senyawa aktif antimikroba. Pengujian aktivitas antibakteri pada penelitian ini menggunakan Pseudomonas fluorescens FNCC 0071 yang merupakan bakteri pembusuk yang dapat menimbulkan berbagai jenis kerusakan bahan pangan (Andriani et al., 2012). Sari (2014) menjelaksan bahwa tingkat sensitivitas antimikroba tinggi apabila diameter zona hambat $>12 \mathrm{~mm}$, diameter zona hambat 9$12 \mathrm{~mm}$ sensitivitas sedang, sensitivitas rendah dengan diameter berkisar antara 6-9 $\mathrm{mm}$ dan resisten apabila $<6 \mathrm{~mm}$. Pada penelitian ini tingkat sensitivitas antimikroba oleoresin daun kayu manis dua tahap termasuk dalam sensitivitas antimikroba tinggi karena diameter zona bening penghambatan mikroba lebih dari $12 \mathrm{~mm}$, yaitu berkisar antara 21,766-31,394 $\mathrm{mm}$.

Menurut Schlegel dan Schmidt (1994) ukuran zona penghambatan antimikroba dipengaruhi oleh sensitivitas senyawa antimikroba, medium kultur, kondisi inkubasi, dan kecepatan difusi agar. Faktor-faktor yang mempengaruhi kecepatan difusi agar, yaitu konsentrasi mikroorganisme, suhu inkubasi, waktu inkubasi, dan komposisi media yang digunakan. Ponce et al. (2008) menjelaskan bahwa komponen aktif pada film dengan penambahan minyak atsiri mempunyai kemungkinan penguapan lebih tinggi daripada oleoresin, hal ini disebabkan kandungan senyawa non volatil dalam oleoresin.

Pseudomonas fluorescens tergolong dalam bakteri gram negatif (Moore et al., 2006). Eugenol dan linalool pada oleoresin daun kayu manis dua tahap dapat menghambat bakteri gram positif dan gram negatif (Sienkiewicz et al., 2014). Linalool merupakan golongan alkohol tersier. Mekanisme golongan alkohol dalam menghambat pertumbuhan bakteri gram negatif pada penelitian ini dengan cara mendenaturasi protein. Bobot molekul alkohol berhubungan dengan perannya sebagai antimikroba, apabila bobot molekul alkohol meningkat maka aktivitas antimikroba juga akan meningkat (Kusumawardani et al., 2008).

Pada penelitian Khasanah et al. (2017b) senyawa aktif mayoritas oleoresin daun kayu manis satu tahap adalah eugenol sebesar 59,56\%. Singh et al. (2007) juga menjelaskan bahwa minyak atsiri dan oleoresin daun kayu manis mempunyai kandungan senyawa aktif eugenol sebesar 87\%, eugenol merupakan kelompok senyawa fenol. Daya antibakteri minyak atsiri dalam oleoresin daun kayu manis dua tahap disebabkan oleh adanya senyawa fenol akan dapat mendenaturasi protein sel bakteri dengan cara melarutkan lemak yang terdapat pada dinding sel. Mekanisme kerja senyawa antimikroba diawali dengan penghambatan sintesis dinding sel. Tidak berlangsungnya transport senyawa dan ion ke dalam sel bakteri terjadi karena kerusakan membran sel sehingga bakteri mengalami kekurangan nutrisi untuk pertumbuhannya dan akhirnya mati (Sari, 2014). Mekanisme penghambatan eugenol terhadap bakteri gram negatif pada penelitian ini, selain mendenaturasi protein juga dengan merusak membran sitoplasma. Hal ini mengakibatkan fosfolipida tidak dapat mempertahankan bentuk membran sitoplasma, sehingga pertumbuhan bakteri akan terhambat (Kusumawardani et al., 2008).

\section{KESIMPULAN}

Penambahan oleoresin daun kayu manis dua tahap $(0 \%, 0,025 \%, 0,5 \%, 0,075 \%$, dan $0,1 \%)$ tidak berpengaruh terhadap ketebalan, kuat tarik, dan laju transmisi uap air edible film, namun berpengaruh terhadap pemanjangan dan penghambatan mikroba edible film. Diketahui bahwa edible film dengan penambahan oleoresin daun kayu manis konsentrasi $0,1 \%$ menghasilkan karakteristik fisik dan penghambatan mikroba yang terbaik, yakni dengan ketebalan $0,128 \mathrm{~mm}$, kuat tarik 0,2189 MPa, pemanjangan 283,2721\%, laju transmisi uap air $29,786 \mathrm{~g} / \mathrm{jam} . \mathrm{m}^{2}$, dan zona bening penghambatan mikroba $31,394 \mathrm{~mm}$.

\section{ACKNOWLEDGEMENT}

Peneliti mengucapkan terima kasih kepada Universitas Sebelas Maret Surakarta yang telah membiayai penelitian ini melalui PNBP UNS Tahun Anggaran 2015 dengan nomor kontrak penelitian No: 624/UN27.11/PL/2015. 


\section{DAFTAR PUSTAKA}

Andriani, M.A.M., Utami, R. \& Hariyati, L.F. 2012, Aktivitas Antibakteri Berbagai Jenis Madu terhadap Bakteri Pembusuk (Pseudomonas fluorescens FNCC 0071 dan Pseudomonas putida FNCC 0070). Jurnal Biomedika. 5(1), 1-9.

Anggraini, N., Utami, R. \& Kawiji. 2015. Pengaruh Penambahan Minyak Atsiri Rimpang Temulawak (Curcuma xanthorriza Roxb) pada Edible Coating terhadap Stabilitas pH dan Warna Fillet Ikan Patin selama 4 Bulan Penyimpanan Suhu Beku. Jurnal Teknosains Pangan. 2(4), 39-45.

Ayuningrum, Z.K. 2015. Pengaruh Minyak Atsiri Kulit Batang Kayu Manis (Cinnamomum burmannii) terhadap Karakteristik Edible film dan Kualitas Daging Segar (Skripsi S1) Surakarta: Universitas Sebelas Maret.

Azzahra, FA, Utami, R. \& Nurhartadi, E. 2013. Pengaruh Penambahan Minyak Atsiri Lengkuas Merah (Alpinia purpurata) pada Edible Coating terhadap Stabilitas $\mathrm{pH}$ dan Warna Fillet Ikan Patin selama Penyimpanan Suhu Beku. Jurnal Teknosains Pangan. 2(4), 32-38.

Badan Standarisasi Nasional. 2009. SNI 3148. Sapi Potong. Jakarta.

Badan Standarisasi Nasional. 2014. Produksi Sapi. Jakarta.

Bao, Vo Van Q \& T Thi Minh, Hanh. 2008. Study on Manufacturing Edible Film from Cassava Starch and its Application in Candy Packing Techniques. University Of Technology, Da Nang University.

Belibi, PC, TJ, Daou, JMB, Ndjaka, B, Nsom, L, Michelin, \& B, Durand. 2014. A Comparative Study of Some Properties o Cassava and Tree Cassava Starch Films. Journal of Physics Procedia. 55(1), 220-226.

Bourtoom, T. 2008. Edible Films and Coatings: Characteristics and Properties. International Food Research Journal. 15(3), 237-248.

Bukhori, A. 2011. Pengaruh Variasi Konsentrasi Gliserol Terhadap Karaktersitik Edible film Berbahan Tepung Jali (Cix lacryma-jobi L.) (Skripsi). Surakarta: Universitas Sebelas Maret
Detduangchan, N, W, Sridach, \& T, Wittaya. 2014. Enhancement of the properties of biodegradable rice starch films by using chemical crosslinking agents. International Food Research Journal. 21(3), 1225-1235.

Emiroglu, Z, Karagoz., GP, Yemis, BK, Coskun, \& K, Candogan. 2010. Antimicrobial Activity of Soy Edible Films Incorporated with Thyme and Oregano Essential Oils on Fresh Ground Beef Patties. Meat Science. 86(1), 283-288.

Ghasemlou, M, N, Aliheidari, R, Fahmi, SS, Aliabadi, B, Keshavars, MJ Cran, \& R, Khaksar. 2010. Physical, Mechanical and Barrier Properties of Corn Starch Films Incorporated with Plant Essential Oils.

Gontard, N, Guilbert, S, \& Cuq, JL. 1993. Water And Glycerol As Plasticizer Affect Mechanical And Water Barrier Properties Of An Edible Wheat Gluten Film. Journal of Food Science. 58(1), 206-211.

Katili, S, BT, Harsunu, \& S, Irawan. 2013. Pengaruh Konsentrasi Plasticizer Gliserol dan Komposisi Khitosan dalam Zat Pelarut terhadap Sifat Fisik Edible film dari Khitosan. Jurnal Teknologi. 6(1), 29-38.

Kavoosi, Gholamreza., A, Rahmatollahi, SMM, Dadfar, AM, Purfard. 2014. Effects of Essential Oil on the Water Binding Capacity, Physicomechanical Properties, Antioxidant and Antibacterial Activity of Gelatin Films. Food Science and Technology. 57(2), 556-561.

Kawiji, R, Utami, LU, Khasanah, \& RT, Nurdiani. 2013b. Pengaruh Penambahan Oleoresin Daun Jeruk Purut (Citrus hystrix Dc) Pada Coating Terhadap Penghambatan Kerusakan Oksidatif dan Mikrobiologis Daging Sapi yang disimpan di Suhu Rendah. Jurnal Teknologi Hasil Pertanian. 7(1), 1-10.

Kawiji., R, Utami, \& A, Setiawan. 2013a. Pengaruh Penambahan Minyak Atsiri Rimpang Temulawak (Curcuma xanthorizza Roxb) pada Edible Film terhadap Karakteristik Organoleptik dan Antimikrobia. Jurnal Teknosains Pangan. 2(3), 9-13.

Khairina, AF. 2014. Pengaruh Variasi Konsentrasi Oleorsin dan Bahan Penyalut Maltodekstrin terhadap Karakteristik Fisik dan Kimia Mikroenkapsul Oleoresin Daun Kayu Manis (Cinnamomum burmannii) Dua Tahap (Skripsi S1). Surakarta: Universitas Sebelas Maret. 
Khasanah, LU, BK Anandhito, Q Uyun, R Utami \& GJ Manuhara. 2017a. Optimasi Proses Ekstraksi dan Karakterisasi Oleoresin Daun Kayu Manis (Cinnamomum burmannii) Dua Tahap. Indonesian Journal of Essential Oil. 2(1), 20-28.

Khasanah, LU, Kawiji, P Prasetiawan, R, Utami, GJ Manuhara, AP Sanjaya. 2017b. IOP Conf. Series: Materials Science and Engineering. 193, 012021

Khasanah, LU, R, Utami, BK, Ananditho, \& AE, Nugraheni. 2014. Pengaruh Penambahan oleoresin 0,1\% Pendahuluan Fermentasi Padat dan Fermentasi Cair Terhadap Rendemen dan Karakteristik Mutu Minyak Atsiri Daun Kayu Manis. Jurnal Agritech. 34(1), 36-41.

Krochta, JM \& C, De Muller-Johnson. 1997. Edible and biogedrable polymer films. Journal of Food Technology. 51(2), 61-74.

Kusumawardani, IR, R, Kusdarwati, \& D, Handijatno. 2008. Daya Anti Bakteri Ekstrak Jahe Merah (Zingiber officinale Rosc.) Dengan Konsentrasi Yang Berbeda Terhadap Pertumbuhan Aeromonas hydrophila Secara In Vitro. Jurnal Berkala Ilmiah Perikanan. 3(1), 75-81.

Kusumawati, DH \& WDR, Putri. 2013. Karakteristik Fisik dan Kimia Edible film Pati Jagung yang Diinkorporasi dengan Perasan Temu Hitam. Jurnal Pangan dan Agroindustri. 1(1), 90-100.

Lagos, JB, NM, Vincentini, RMCD, Santos, AMQBB, Bittante, \& PJA, Sobral. 2015. Mechanical Properties of Cassava Starch Films As Affected By Different Plasticizers and Different Relative Humidity Conditions. International Journal of Food Studies. 4(1), 116-125.

Ma, Wen, CH, Tang, SW, Yin, XQ, Yang, Q, Wan, F, Liu, et al. 2012. Characterization of Gelatin Based Edible Films Incorporated With Olive Oil. Food Research International. 49(1), 572-579

Maghfiroh., W, Sumarni, \& B, Susatyo. 2013. Sintesis dan Karakterisasi Edible film Kitosan Termodifikasi PVA dan Sorbitol. Indonesian Journal of Chemical Science. 2(1), 1-6.

Mali, S, LS, Sakanaka, F, Yamashita, \& MVE, Grossmann. 2005. Water Sorption and Mechanical Properties of Cassava Starch
Films and Their Relation to Plasticizing Effect. Journal of Carbohydrate Polymers. 60(3), 283-289.

Manab, A, Sawitri, ME, Al Awwaly, KU, \& Purnomo, H. 2011. Antimicrobial Activity of Whey Protein Based Edible Film Incorporated with Organic Acids. African Journal of Food Science. 5(1), 6-11.

McHugh, TH, Aujard, J F, \& Krochta JM. 1994. Plasticized whey protein edible films: Water vapor permeability properties. Journal of Food Science. 59(2), 416-419. doi: 10.1111/j.13652621.1994.tb06980.x

Moore, Edward R, BJ, Tindall, Vitor, AP, MD, Santos, DH, Pieper, JL, Ramos, \& NJ, Palleroni. 2006. Nonmedical: Pseudomonas. Prokaryotes. 6(1), 646-703.

Nonsee, K, C, Supitchaya, \& W, Thawien. 2011. Antimicrobial Activity and the Properties of Edible Hydroxypropyl Methylcellulose Based Films Incorporated with Encapsulated Clove (Eugenia caryophyllata Thunb.) Oil. International Food Research Journal. 18(4), 1531-1541.

Nugraheni, KS. 2012. Pengaruh Penambahan oleoresin 0,1\% Pendahuluan dan Metode Destilasi terhadap Karakteristik Mutu Atsiri Daun Kayu Manis (Cinnamomum leaf oil burmannii) (Skripsi S1). Surakarta: Universitas Sebelas Maret.

Nugroho, AA, Basito, \& RBK, Anandito. 2013. Kajian Pembuatan Edible film Tapioka dengan Pengaruh Penambahan Pektin Beberapa Jenis Kulit Pisang terhadap Karakteristik Fisik dan Mekanik. Jurnal Teknosains Pangan. 2(1), 7377.

Park, JW, Testin, RF, Vergano, DJ, Park, KJ, \& Weller, CL. 1996. Application of Laminated Edible Film to Potato Chip Packaging. Journal of Food Science. 61(4), 66-76.

Pires, C, C, Ramos, G, Teixeira, L, batista, R, Mendes, L, Nunes, \& A, marques. 2011. Characterization of Biodegradable Films Prepared with Hake Proteins and Thyme Oil. Journal of Food Engineering. 105(1), 422428.

Ponce, AG, SI, Roura, CED, Valle, \& MR, Moreira. 2008. Antimicrobial and Antioxidant Activities of Coatings Enriched with Natural Plant Extracts: In Vitro and In Vivo Studies. 
Journal of Postharvest Biology and Technology. 49(1), 294-300.

Rahayoe, S, Rocmadi, Wiratni, S, Syamsiyah, \& J, Shigiro, 2014, Perilaku Viskositas Larutan Pelapis Kitosan dengan Variasi Konsentrasi Penambahan Aditif. Seminar Nasional Sinergi Pangan Pakan dan Energi Terbarukan, Hal. 68.

Resianingrum, R, W, Atmaka, LU, Khasanah, Kawiji, R, Utami, \& D, Praseptiangga. 2016, Characterization of cassava starch-based edible film enriched with lemongrass oil (Cymbopogon citratus), Nusantara Bioscience, 8(2), 278-282.

Rofikah. 2013. Pemanfaatan Pektin Kulit Pisang Kepok (Musa Paradisiaca Linn) Untuk Pembuatan Edible Film (Skripsi S1). Semarang: Universitas Negeri Semarang.

Sabrina, MR, LU, Khasanah, RBK, Anandito, \& R, Utami. 2014. Aplikasi Coating Pati Tapioka dengan Penambahan Oleoresin Kayu Manis (Cinnamomum burmannii) sebagai Antioksidan Alami pada Sosis Sapi. Prosiding. Seminar Nasional Sinergi Pangan dan Energi Terbarukan, hh. 18-22.

Sari, DR, SB, Prayitno, \& Sarjito. 2014. Pengaruh Perendaman Ekstrak Bawang Putih (Allium sativum) Terhadap Kelulushidupan Dan Histologi Ginjal Ikan Lele (Clarias gariepinus) Yang Diinfeksi Bakteri "Edwardsiella Tarda". Journal of Aquaculture Management and Technology. 3(4), 126-133.

Schlegel, HG, \& Schmidt, K. 1994. Mikrobiologi Umum. Yogyakarta: Gajah Mada University Press.

Sepheri, N, \& M, Armin. 2015. Application of Coating and Their Effect on Food Storage. Juornal of GMP Review. 16(4), 328-330.

Sienkiewicz, M, A, Glowacka, E, Kowalczyk, AW, Owczarek, MJ, Bebenista, \& M, Łysakowska. 2014. The Biological Activities of Cinnamon, Geranium and Lavender Essential Oils. Journal of Molecules. 19(1), 20929-20940.

Sinaga, LL, MS, Rejekina S, \& MS, Sinaga. 2013. Karakteristik Edible Film dari Ekstrak Kacang Kedelai dengan Penambahan Tepung Tapioka dan Gliserol sebagai Bahan Pengemas Makanan. Jurnal Teknik Kimia USU. 2(4).

Singh, G, S, Maurya, MP, Delampasona, \& CAN, Catalan. 2007. A Comparison of Chemical, Antioxidant and Antimicrobial Studies of Cinnamon Leaf and Bark Volatile Oils, Oleoresins and Their Constituents. Journal of Food and Chemical Toxicology. 45 (1), 16501661.

Siswanti., R.B.K, Anandito, \& GJ, Manuhara. 2013. Karakterisasi Edible Film Komposit dari Glukomanan Umbi Iles-Iles (Amorphopallus muelleri blume) dan Maizena. Jurnal Teknologi Hasil Pertanian. 6(2), 1-7.

Skurtys, O, C, Acevedo, F, Pedreschi, J, Enrions, F, Osorio, \& JM, Aquilera. 2011. Food Hydrocolloid Edible Films and Coating. Department of Food Science and Technology, Universidad de Santiago de Chile.

Souza, AC, GEO, Goto, JA, Mainardi, ACV, Coelho, \& CC, Tadini. 2013. Cassava Starch Composite Films Incorporated with Cinnamon Essential Oil: Antimicrobial Activity, Microstructure, Mechanical and Barrier Properties. Journal of Food Science and Technology. 54(1), 346-352.

Suliantari, B, SL, Jenie, MT, Suhartono, \& A, Apriyanto. 2008. Journal of Aquaculture Management and Technology. Jurnal Teknologi dan Industri Pangan. 19(1), 1-6.

Susanti, N, IM, Gandidi, MD, \& Susila ES. 2013. Potensi Produksi Minyak Atsiri Dari Limbah Kulit Kayu Manis Pasca Panen. Jurnal FEMA. 1( 2), 45-49.

Tampubolon, DF. 2011. Isolasi Dan Analisis Komponen Kimia Minyak Atsiri Daun Kayu Manis (Cinnamomum Burmanii) Dengan Cara Gc - Ms. (Skripsi S1) Medan: Universitas Sumatera Utara.

Taqi, A, KA, Askar, K, Nagy, L, Mutihac, \& L, Stamatin. 2011. Effect of Different Concentrations of Olive Oil and Oleic Acid on the Mechanical Properties of Albumen (Egg White) Ediblefilms. African Journal of Biotechnology. 10(60), 12963-12972.

Tasia, WRN, \& TD, Widyanigsih. 2014. Potensi Cincau Hitam (Mesona palustris Bl.), Daun Pandan (Pandanus amaryllifolius) Dan Kayu Manis (Cinnamomum burmannii) Sebagai Bahan Baku Minuman Herbal Fungsional. 
Jurnal Pangan dan Agroindustri. 2(4), 128136.

Tongdeesoontorn, W, LJ, Mauer, S, Wongruong, P, Sriburi, \& P, Rachtanapun. 2011. Effect of Carboxymethyl Cellulose Concentration on Physical Properties of Biodegradable Cassava Starch-Based Films. Chemistry Central Journal. 5(6), 1-8.

Towaha, J. 2012. Manfaat Eugenol Cengkeh Dalam Berbagai Industri Di Indonesia. Jurnal Perspektif. 11(2), 79-84.

Utami, R, E, Nurhartadi, \& AYT, Putra. 2013. Pengaruh Penambahan Minyak Atsiri Kunyit Putih (Kaempferia rotunda) pada Edible Film Pati Tapioka terhadap Aktivitas Antimikroba dan Sensoris. Jurnal Teknosains Pangan. 2(2), 51-56.

Utami, R, Kawiji, E, Nurhartadi, AYT, Putra, A, Setyawan. 2014. The effect of cassava starchbased coating enriched with Kempferia rotunda and Curcuma xanthorrhiza essensial oil on refrigerated patin fillets quality. International Food Research Journal. Vol. 21(1), 413-419.

Utami, R, Kawiji, LU, Khasanah, \& Nasution, MIA. 2017. Preservative Effects of Kaffir Lime (Citrus hysteric DC) Leaves Oleoresin Incorporation on Casava Starch-Based Edible Coatings for Refrigerated Fresh Beaf. IFRJ. 24(4), 1464-1472.

Warkoyo, B, Rahardjo, DW, Marseno, \& JNW, Karyadi. 2015. Kinetika Pertumbuhan Mikrobia Dan Kemunduran Mutu Bakso Daging Terlapisi Pati Umbi Kimpul (Xanthosoma sagittifolium) yang Diinkorporasi Kalium Sorbat. Jurnal Agritech. 35(1), 61-67.

Winarti, C, Miskiyah, \& Widaningrum, 2012, Teknologi Produksi Dan Aplikasi Pengemas EdibleAntimikroba Berbasis Pati, Jurnal Litbang Pertanian. 31(3), 85-93.

Yulianti, R \& E, Ginting. 2012. Perbedaan Karakteristik Fisik Ediblefilm dari Umbiumbian yang Dibuat dengan Penambahan Plasticizer. Penelitian Pertanian Tanaman Pangan. 31(2), 181-184.

Yustina, I, E, Nurvia A, \& Aniswatul. 2012. Pengaruh Penambahan Aneka Rempah terhadap Sifat Fisik, Organoleptik serta Kesukaan pada Kerupuk dari Susu Sapi Segar.
Seminar Nasional Kedaulatan Pangan dan Energi Fakultas Pertanian Universitas Trujono Madura. Madura.

Zhong, QP, \& WS, Xia. 2008. Physicochemical Properties of Edibleand Preservative Films from Chitosan/Cassava Starch/Gelatin Blend Plasticized with Glycerol. Food Technol. Biotechnol. 46(3), 262-269.

Zhou, J, Zhang, J, Ma, Y, \& Tong, J. 2008. Surface Photo-Crosslinking of Corn Starch Sheets, Carbohydrate Polymer. 74(1), 405410. 